Ana Gardašević, pedagog 1

Predškolska ustanova „Dečja radost“ Ćuprija
Primljen: 23.2.2021.

Prihvaćen: 22.6.2021.

UDC: $37.018 .1: 371.382$

37.018.1:796.11

STRUČNI NAUČNI RAD

DOI: $10.19090 /$ ps.2021.1.26-40

\title{
KOLIKO JE PODRŽANO DETE U IGRI U KUĆNIM USLOVIMA ${ }^{2}$
}

\begin{abstract}
Apstrakt
U radu su prikazani i analizirani rezultati dobijeni istraživanjem dečje igre $i$ podrške roditelja deci u kućnim uslovima tokom pandemije Covid-19. Igra je prirodan način učenja u životu deteta, ali je roditelji često koriste za rešavanje obrazovnih zadataka i pretvaraju igru u podučavanje. Polazna osnova za istraživanje je potreba da se analizira uloga roditelja u odnosu na teorijsku analizu poželjnih uloga odraslih u igri dece. Namera istraživanja je da roditelji iz svoje perspektive ocene svoju igru kada su bili deca i igru njihove dece i da sagledaju sopstvenu ulogu, koju preuzimaju u zajedničkoj igri sa njima. Rezultati su ukazali da je igra roditelja kada su bili deca bila kvalitetnija od igre njihove dece danas i da je igra njihove dece više usamljenička. Roditelji preuzimaju indirektnu ulogu tokom podrške dečjoj igri, manje se direktno ukučuju u igru dece. Više su u ulozi posmatrača, a najmanje kao pomoćnici i partneri u igri. Ovako dobijeni rezultati su bili polazište za preduzimanje koraka koji bi doprineli kvalitetnijoj podršci i uspostavljanju partnerstva u igri dece i odraslih. Naredni korak je bio predstavljanje moguće igre dece u kućnim uslovima, gde je uloga roditelja pomerena sa uloge posmatrača u ulogu saigrača i partnera.
\end{abstract}

Ključne reči: igra, kontekst, participacija, strategija podsticanja igre

\section{Uvod}

Igra je važna u životu svakoga, ali je najvažnija u periodu detinjstva, zato i kažemo da je igra dragocenost detinjstva. Igra je za dete nezamenljiv i prirodan način

1 ana.gardasevic@gmail.com

2 Ovaj članak predstavlja rezultat istraživanja igre dece i roditelja u kućnim uslovima, tokom trajanja pandemije i saradnje dece, roditelja i praktičara vrtića na unapređivanju igre koji će biti predstavljen na XIV Stručnim susretima stručnih saradnika Predškolskih ustanova Srbije; nastale igre prikazane su linku https://padlet.com/anagardasevic/9hhk03fc90uqv1kh 
učenja od prvog dana života. Pomoću igre dete istražuje i bogati saznanja o sebi i svetu koji ga okružuje. Igrati se sa detetom znači stvoriti prilike za dete da saznaje, otkriva i ovladava svojim veštinama. To takođe za odraslog znači priliku da upozna način na koji dete misli, zaključuje, oseća i doživljava stvarnost. Kada je dete sasvim malo, roditelji su za njega nezamenljiva igračka i najzanimljivija im je igra sa roditeljima. Zahvaljujući toj interakciji, bebe najviše uče i najviše se razvijaju. Igra je važna jer je ona i najviši oblik istraživanja. Ona je slobodna i ne nosi rizik od neuspeha. Igra je sama sebi cilj, neponovljiva je po toku i ishodu, unutrašnje motivisana, spontana ispunjena pozitivnim emocijama.

Kada se posmatra učešće odraslih u igri, igra se često stavlja u službu podučavanja ili se pak sasvim prepušta deci „u prirodnom stanju“. U prvom slučaju igra gubi onaj smisao koji ima za dete, jer treba da proističe iz potrebe deteta, a ne da bude zadata od strane odraslih. U razgovoru sa jednim roditeljem na pitanje, kako se igra sa svojim trogodišnjim detetom odgovor je da ga „uči da prepozna slovo sa kartice“, čime svoju igru pretvara u obrazovni zadatak. Još u vreme Frebelovih vrtića, Tolstoj je prepoznao tutorsku ulogu odraslih i rekao da se u njima ,deca igraju plačući“ (Marjanović, 1987:97). U drugom slučaju dete je potpuno prepušteno sebi, a uloga odraslog nevidljiva. U takvom okruženju igra deteta je neproduktivna jer dete nema dovoljno iskusta u igri, a ako je još i nestimulativna sredina, onda je igra još siromašnija.

\section{Igra dece na ranom uzrastu „Učiti svoje dete znanju ne treba silom, nego igrom “ Platon}

"Igra nije ništa manje složena i zagonetna od stvaralaštva... Samo je dete u stanju da u igri upotrebi predmet na način koji prevazilazi svrhu i namenu, u jednom potpunom novom smislu: štap u igri deteta postane konj, list tanjir, kamenčić sapun i samo dete može da se transformiše u oca, konduktera, fudbalera, pa čak i u čudovište koje nema uzora ni u jednoj realnoj situaciji” (Marjanović, 1987:89).

„Igra nema ciljeve kojima služi, ona svoje ciljeve i svoj smisao ima u samoj sebi. Igra nije radi nekog budućeg blaženstva, ona je sebi već sreća“ (Nives M, prema Duran, 2015:13). Igra je aktivnost koja se odigrava sama za sebe, karakterišemo je kao sredstvo a ne kao cilj, jer je važniji proces od bilo kog krajnjeg ishoda. Ona je fleksibilna, jer se predmeti stavljaju u nove kombinacije, ili se koriste na nove načine i pozitivna je, jer ima pozitivan efekat i deca su uvek zadovoljna u igri (Smith, Pellegrini, 2013:7). "Igra je više od sredstva za postizanje cilja, ma koliko ti ciljevi bili visoko vrednovani od strane roditelja i vaspitača" (Marjanović prema Sutton- Smith, 1988).

Postoje različiti kriterijumi dečjih igara. Teško je naći kriterijume koji bi obuhvatili potpunu i sveobuhvatnu klasifikaciju igara, jer se kriterijumi klasifikacije često mešaju. Zato u literaturi često susrećemo veliki broj različitih kriterijuma za istraživanje igre. To su aspekti razvoja, tipovi aktivnosti, sadržaji igre, mesto igre, broj 
učesnika, interakcija odnosi između učesnika u igri, pravila u igri, igračke i materijali i uloga u igri.

Pijaže je delio igre na senzomotorne, simboličke igre i igre sa pravilima. Sutton - Smith na sobne igre, igre sa vršnjacima i roditeljima, simboličke igre, igre pretvaranja i igre veština. Neki od kriterijuma mogu da budu aspekti razvoja (kognitivne, motorne i društvene igre). Mirjana Duran je delila igru na osnovu interakcije (Duran, 2001:117-140), odnose između učesnika u igri (dijaloške igre, timske igre, ja-ti, ja-vi, mi-oni).

Kamenov igre deli u četiri kategorije: funkcionalne, igre mašte ili igre uloga, igre sa gotovim pravilima i konstruktivne igre. (Kamenov, 2006:64).

Funkcionalne igre definišu se kao igre u kojima vršenje pokreta nema neposrednu svrhu, nemaju određeni cilj, već izaziva kod deteta zadovoljstvo što se njima ovladalo. Ove igre mogu biti senzomotorne aktivnosti sopstvenim organima (brzi pokreti bez igračaka), igre posvećene rukovanju materijala (sportskim rekvizitima, prirodnim i veštačkim materijalima, vodom), pokretne igre uz korišćenje rekvizita (vožnja bicikla, klackanje) i igre glasovima, slogovima i rečima.

Igre uloga, imitativne igre, odnosno igre imitacije i podražavanja, iluzije, dramske, fikcije su igre u kojima se dete prepušta mašti, zamišlja i improvizuje stvarnost. Oblici javljanja ovih igara mogu biti kroz oponašanje postupaka (zamene upotrebe predmeta), simboličku imitaciju (podržava dete samo sebe u zamišljenim situacijama), simbolička igra uloga sa sižeom (preuzimanje uloge odraslih ili druge osobe i prikazuje njihove međusobne odnose i ponašanja), dramske igre uloga (složeno izvođenje dramatizovanog teksta sa podelom uloga).

Igre sa gotovim pravilima mogu biti za podsticaj perceptivno-motorne aktivnosti, zdravstveno-higijenske, društvene aktivnosti, afektivne, ekološke, otkrivačke, logičko-matematičke, praktične aktivnosti i aktivnosti koje unapređuju komunikaciju i stvaralaštvo.

Konstruktorske igre $u$ kojima deca uobličavaju materijale mogu se javiti u obliku pronalaženja kombinacija nastalim nenamernim oblikovanjem materijala, oblikovanje, ređanje materijala, grafičko predstavljanje, građenje gotovim materijalom i organizovanje materijala, utilitarne konstrukcije (u prvi plan stavljaju upotrebljivost materijala). (Kamenov, 2006:64-68)

\section{Igra i dete kao aktivni učesnik u građenju socijalnih, izazovnih, istraživačkih potreba}

Igra je potreba svakog deteta. Brojni su pokazatelji da igra razvija kognitivne, socijalne aspekte koji su ključni za razvoj komplesnih načina učenja, odnosno ,preduslov za učenje složenih koncepata kako deca stare“ (Leong, Bodrova, 2005:3). Igra je podrška razvoju „pamćenja, samoregulacije, pažnje, jezika i prepoznavanja simbola“ (Leong, Bodrova, 2005:3). Ona utiče na prilagođavanje deteta u društvu i direktno je 
povezana sa razvojem predčitalačkih veština. Stupajući u odnose sa vršnjacima tokom igre, deca stiču socijalne veštine, koje ne bi mogla steći ako bi samo bili pred računarima, lišeni prirodnih kantakata sa drugima. Prema Pjažeu, dete treba samo da istražuje, ,jer samo slobodno istraživanje i samostalni napori deteta mogu proizvesti pozitivne rezultate" (Matejić Đuričić prema Pjaže, 2012:272), a ti rezultati su važni za opšti školski uspeh ali i za tokove civilizacije i društva. Važnost pridajemo i transgeneracijskom učenju, učenju od dece starijeg uzrasta. Starija deca su preuzimala brigu i mentorstvo nad mlađom, predstavljala za njih uzore, tako je deci bio omogućen lakši način učenja po modelu koji je širio sociokulturne vidike svoj deci. Takvo učenje je sve manje prisutno, jer su različiti konteksti odrastanja dece, gde je prisutan manji broj dece, pa se ne može ovakav način učenja obezbediti.

Dete se rađa sa potrebom da uči i da se razvija. Rane stimulacije su važne kako bi se nesmetano odvijao razvoj. Dete najbolje uči kada se suočava sa izazovima, kada odrasli ne ometaju njegovu inicijativu, već mu stvaraju prijatan podsticajni ambijent. Podsticaji treba da budu što prirodniji, jer učenje treba da se odvija kroz sticanje iskustava. Zato je igra najvažniji vid učenja dece, ona je jedna od najvažnijih potreba koju dete ima. Igra detetu služi da nauči kako svet funkcioniše, kako da reguje u različitim situacijama, kako da ovladava svojim emocijama i kako da razume tuđe. Igra utiče na građenje odnosa sa drugima, ona podstiče celokupan razvoj deteta.

Tokom igre dete gradi identitet, u interakciji je - komunicira, istražuje i konstruiše, transformiše i razvija maštu. (Krnaja, 2012:119). Pred dete se postavljaju različiti zahtevi, koji treba da se usklade sa kulturom kojoj dete pripada. Dete postaje član kulture, učeći kroz igru o kulturi. U odnosu na shvatanja u određenom društvu o važnosti igre za dete i razvoj deteta, zavisi koliko će detetu biti dozvoljeno da razvija maštu i svoje kapacitete igrajući se. Izbor igračaka je uslovljen kulturom i shvatnjem važnosti igrovnih sredstava za učenje dece u određenom društvu. (Krnaja, 2012:123)

Okuženje deteta igra veliku ulogu u sticanju iskustva u igri. Igra se razvija u odnosu na individualne sposobnosti, potencijale deteta i interakciju deteta sa okruženjem. Sama igra sa ponuđenim sredstvima, materijalima je podsticajna i značajna za dete, ukoliko postoji podržavajuća atmosfera, ukoliko se detetu šalje poruka prihvatanja.

Prema M. Duran postoje tri osnovna načina igrovne interakcije, koje razvrstavamo u tri grupe: igre u kojima je interakcija među pojedincima, igre u kojima je interakcija između glavnog igrača i ostalih, igre u kojima je interakcija uređena između grupa (Duran, 2001:117-140).

\section{Uticaj odraslih na stvaranje iskustva kod dece u igri „Najveći čovek uvek ostaje dete" - Johan Volgang fon Gete}

Svako dete je jedinstveno po pitanju toka svog razvoja, iskustva koje stiče, sposobnosti koje je steklo i koje može potencionalno razviti. Uloga odraslog je da sagleda dečje kapacitete, razume dečje potrebe i utiče podsticajno na dete kako bi ono na način 
na koji želi učilo, odrastalo. Važno je da odrasli prate dečju inicijativu, interesovanja i osećaj sigurnosti i uvaženosti, omogućuje mu da bude samostalno jer dete bira igru, donosi odluke vezane za igru i osmišljava pravila. U toku igre se ispoljavaju različite emocije, sama igra bogati pozitivne emocije deteta i odraslih. Putem igre se deca susreću sa različitim junacima pozitivnim i negativnim i za njih vežu različita osećanja i doživljaje. Uloga odraslih je da podrže decu da istražuju emocije negativnih likova i razmišljaju o načinima na koji se mogu postupci likova izmeniti.

„U porodičnom kontekstu, uključivanje roditelja u dečju igru dovodi do višeg kvalitativnog nivoa igre“ (Colić, Milošević, 2019: 161). „Neposredno i aktivno učešće odraslih u igri dece ističu brojni autori kao značajno za viši nivo kvaliteta, duže trajanje i veću složenost igre“ (Colić, Milošević, 2019:165 prema Guyton, 2011; Rengel 2014; Sung, 2018 i drugi). Delovanje odraslih u igri dece je za decu značajno, oni stiču iskustva, grade odnose, uče kako da sarađuju i svoju igru produbljuju ispitujući različita rešenja. Deca najviše vremena provode u porodici, veliki deo tog vremena provode igrajući se, zato je važno koliki se značaj pridaje dečjoj igri, kako roditelji razumeju dečju potrebu za igrom i kako je podržavaju. U igri je važno detetu dati dovoljno vremena da integriše sve što čuje, vidi, doživljava i ponudi svoj odgovor kao nastavak interakcije. $U$ toj interakciji roditelj ne bi trebalo da ima vodeću ulogu iako ima više iskustva i znanja od deteta. Igru ne treba da vodi roditelj, već da u igri bude sa detetom, a ne nad detetom. Neizvesnost i tok igre prepuštamo situaciji i dečjoj inicijativi. Često roditelji se ne ukučuju u igru dece, jer smatraju da im je igra zabava, ne shvataju važnost njihovog učešća u igri. Nekada se uključuju tako što vode igru, a nekada kao partneri u igri, unapređuju kompetencije dece i podržavaju detetovu inicijativu, daju podršku da se detetova ideja u igri realizuje i na taj način utiču na dobrobit deteta i na njegovu samostalnost.

Delovanje odraslog u igri dece može biti izvan toka igre i unutar toka igre (Badurina prema Hadley, 2015:50). Delovanje izvan toka igre je aktivno posmatranje odraslog, koji svojom komunikacijom proširuje dečju igru, postavljajući deci pitanja sugeriše u kom pravcu može da se odvija igra. Sa druge strane, delovanje unutar toka igre predstavlja direktno i neposredno učešće roditelja u igri sa detetom. Odrasli prate igru dece, ravnopravno učestvuju u igri i uočavaju momenat kada treba da obogate igru. Za potrebe te igre organizuju prostor u saradnji sa detetom, prate tok igre, problematizuju i proširuje koncept igre (na primer u igri gusara roditelj proširiruje igru izradom mape blaga). Odrasli treba da razviju „razigranu narav“, odnosno da budu u kontaktu sa decom u igri, da budu unutar toka dečje igre, da glume sa decom, prepuste se, bez postavljanja pravila (Elliott, Jarneman, prema Hadley 2017:5). Deca na ovakav način unose novine $u$ igru, a to direktno utiče na njihovu spremost za adekvatnije reagovanje u svakodnevnim životnim dešavanjima.

Uloga odraslih u igri uključuje posmatranje, slušanje i dijalog i partnersko uključivanje roditelja (Krnjaja, 2012: 127). Odrasli posmatranjem igre deteta, razumeju značenje igre za dete, obezbeđuju mu sredstva, materijale u odnosu na intere- 
sovanja. Važno je da su odrasli spremni da slušaju decu, da zajedno sa njima traže rešenja. „Od početka deca pokazuju da imaju glas, da umeju da slušaju i žele da ih drugi slušaju“" (Rinaldi, 2001: 3), što ukazuje da je dete biće koje ima potrebu da bude uvaženo, slušano i ima potrebu da čuje i uvaži druga mišljenja. Zato odrasli treba da slušaju dete svim čulima. Slušanje nije u cilju dobijanja odgovora, već ono proizvodi pitanja, nove mogućnosti i materijale kako bi igra bila sadržajnija, a razvijajuće kompetencije za igru kod deteta podržane. Samim tim deca su u dijalogu sa odraslima, a u dijalogu deca opisuju i tumače različite situacije, svoja i tuđa ponašanja. Važno je da tokom razgovora odrasli budu istinski zainteresovani za igru dece, ne dominiraju, već dele zajedničko iskustvo u otkrivanju.

Kada je u komunikaciji između deteta i odraslog obezbeđeno zajedničko slušanje i traganje za smislenim situacijama u zajedničkom učenju, takav odnos je partnerski odnos odraslog u igri sa detetom. Važna je dobra procena odraslog, njegova osetljivost za vreme i način uključivanja sa detetom i vrlo je važno da odrasli stvore izazovne situacije u kojima ima mesta da dete ispolji svoju potrebu za istraživanjem. Odrasli, kao maštoviti saigrači koji se prepuštaju igri, usklađuju svoje akcije sa detetovim i sopstvenu i detetovu kreativnost. Osoba koja stvara „bezbednu neizvestnost“ (Krnjaja, 2012:128), odnosno stvara neizvesne situacije koje podstiču decu na dalje istraživanje, bez nametanja zamisli odraslih u igri, je osoba koja zaista uvažava dete.

I savremena koncepcija „Godine uzleta“ (Pravilnik o osnovama programa predškolskog vaspitanja i obrazovanja, „Godine uzleta“, 2018), podrazumeva direktno $\mathrm{i}$ indirektno učešće u igri dece. Idirektno tako što organizuje fizičku i socijalnu sredinu i direktno tako što stupa u različite oblike interakcije sa decom dok se igraju. Podršku odraslih možemo posmatrati u otvorenoj, proširenoj i vođenoj igri. U otvorenoj igri „deca prema sopostvenoj inicijativi grade igrovni plan i pravila u igri“ (Pravilnik o osnovama programa predškolskog vaspitanja i obrazovanja, „Godine uzleta“, 2018: 21), a odrasli se fokusiraju na pripremanje sredine, praćenje igre, obezbeđivanje dovoljno vremena za igru. U proširenoj igri odrasli „ulaze u određenu ulogu kojom podržava započetu igru“ (Pravilnik o osnovama programa predškolskog vaspitanja i obrazovanja, „Godine uzleta“, 2018: 21), sa decom izrađuje sredstva za igru i proširuje scenario igre. U vođenoj igri „odrasli inicira, učestvuje i usmerava igru pri čemu se dogovara sa decom i pazi da ne naruši igrovni obrazac (dobrovoljnost, imaginaciju, izazov, kreativnost i dinamičnost)“ (Pravilnik o osnovama programa predškolskog vaspitanja i obrazovanja, „Godine uzleta“, 2018, 21-22).

Važnost bavljenja ovom temom, zasniva se na činjenici da je igra veoma važna za celokupni razvoja deteta, podstiče pozitivna osećanja, da je mnogo važna podrška odraslog u dečjoj igri i da postoji vrlo mali broj istraživanja koja govore o tome koliko i na koji način roditelj podržava dete u igri. To se uglavnom podrazumeva, ali u realnosti nije uvek prisutno. Opredelili smo se za ispitivanje načina podrške dečjoj igri u vreme kada su roditelji intezivno provodili vreme sa decom kući, tokom trajanja vanrednog stanja izazvano pandemijom korona virusa. Želeli smo da saznamo kako 
su se nekada roditelji igrali kao deca. Od roditelja smo dobili značajne predloge kako možemo obogatiti igru i omogućiti bolje uslove za njeno razvijanje

\section{Metod}

Predmet ispitivanja odnosi se na podržavanje dečjeg razvoja i učenja, stvaranjem povoljnih uslova za zajedničku igru dece i roditelja. Cilj rada je ispitivanje predstave roditelja o dečjoj igri i njhovoj podršci dečjoj igri. Problem istraživanja zasniva se na tumačenju kvalitativnih istraživačkih pitanja:

(a) Na koji način su se roditelji igrali u svom detinjstvu?

(b) Koje igre igraju najčešće deca danas?

(c) Koji materijali i igračke se koriste u igri današnje dece?

(d) Kako roditelji podržavaju igru svoje dece? Koja je njegova uloga?

(e) Kako podržavati roditelje u bogaćenju dečje igre?

U istraživanju je učestvovalo 134 roditelja Predškolske ustanove „Dečja radost“ iz Ćuprije tokom aprila - maja 2020. Za potrebe istraživanja korišćen je online upitnik otvorenog tipa i analize izveštaja realizacije aktivnosti i igara dece i roditelja u kućnim uslovima. Rezultati istraživanja su ukazali na potrebu unapređivanja roditeljske kompetencije kako bi roditelji bili adekvatna podrška deci u igri i bili saigrači.

\section{Rezultati istraživanja igre dece i roditelja sa diskusijom}

\section{Igra roditelja iz detinjstva}

Po rečima roditelja njihove igre u detinjstvu su bile raznovrsne i pretežno su se odvijale u dvorištima, na ulici gde je bio prisutnan veći broj dece. Igra se odvijala i na igralištima, terasama velikih zgrada, školskom dvorištu, u selu, u dvorištu vrtića.

„Naša druženja i igra se odvijala najviše na ulici, ispred kuće. Skupe se sva deca iz ulice i idemo na vožnju biciklom, igramo između dve vatre, fudbal... ili sedimo na ivičnjaku na ulici i pričamo o nekim dečjim stvarima sa starijom decom, šta nam se dešavalo... ta prijateljstva su ostala $i$ dan-danas.. "

Nije bilo potrebe za nadzorom odraslih. Nije bilo puno gotovih igračaka, pa se igra odvijala u prirodnom ambijentu sa prirodnim materijalima.

„Roditelji su uvek imali obaveze, tako da sam se bar ja uvek igrala sama, ono što igraju devojčice; šila, plela lutkama garderobu, krala iz kuhinje alevu papriku $i$ brašno za kolače, pesak; igrala školica, vozila bicikl sa drugarima; žmurke, lastiš, penjanje po drveću; uglavnom sve ono što deca mala sada nemaju jer su više za kompjuterima, telefonima.. “

Roditelji ističu da su se slobodno kretali, skakali, penjali se po drveću i opisuju taj period sa puno ushićenja, vežu ih lepe uspomene i „dosta oguljenih kolena“. Roditelji navode da tada nije bilo napredne tehnologije i nije bilo čudno doći kod nekoga 
zazvoniti na vrata i pozvati druga na igru. Opisuju ovaj period sa puno osmeha, isčekivanja kada će izaći na igru i iskazuju potrebu da i njihova deca prožive ovakav period detinjstva. Osećanja koja opisuju njihovo detinjstvo su sreća, radost, bezbrižnost, sloboda, sa puno topline i ushićenja.

„Za taj period me vežu jako lepa osećanja. Više je bilo druženja i skupljanja u ulici, zajednička vožnja biciklom, dečjeg smeha dok nas roditelji ne pozovu da uđemo u kuću, tada nije bilo napredne tehnologije. Bolja je bila komunikacija među decom, lepe uspomene... ali ne preko mobilnog telefona; a i naši roditelji su radili i bili smo poslušniji, odgovorniji.."

Dominirala je igra sa drugom decom i u odgovorima roditelja nije prepoznata usamljenička igra dece, uglavnom roditelji navode grupne igre. Ovo govori da je igra imala vodeću ulogu u uključivanju deteta u svet vršnjaka. Deca su učila jedna od drugih o odnosima, modelima ponašanja, pravilima postupanja. Kroz igru su razvijali socijalne kompetencije, veštine komunikacije i saradnje. Najviše je bila prisutna motorička igra sa kojom su usavršavali brzinu, spretnost, dospevali do situacije rizika.

„Igrali smo lastiš, žmurke, jurke, magarac sa kartama, ne ljuti se čoveče, školice, preskakanje vijače, odbojku, fudbal, košarku“.

U odnosu na klasifikaciju interakcije u igri, prema M. Duran, koja se odvijala u igri roditelja kada su bili deca, možemo da zaključimo da su najčešći načini igrovne interakcije bili igre suprostavljanja između grupa kroz igre „,između dve vatre“, sportskim igrama (fudbal, košarka, odbojka). Pored ovih igara igrale su se i igre suprostavljanja između centralnog igrača i ostalih u igrama žmurke, jurke, ćorave bake, šuge. Takođe, su igrali igre suprostavljanja među pojedincima kroz igre školica, igre lastišom, klikerima, igre kartama i „ne ljuti se čoveče“.

$\mathrm{Na}$ osnovu podataka dobijenih od roditelja zaključujem da su pretežno igrali igre bez učešća odraslih, interakcija između dece i roditelja u igri nije bila vidljiva. Prisutna je bila igra koja je podrazumevala saradnju među decom. Nije bila prisutna usamljenička forma igre, samostalna igra, jer je uvek bilo prisutno više dece različitog uzrasta, pa se igra uvek odvijala u interakciji sa njima. Igra se odvijala vremenski dugo, trajala je dok ,roditelji ne pozovu da uđemo u kuću“.

\section{Današnja igra dece u kućnim uslovima}

Jedan broj roditelja navodi da deca u kućnim uslovima najviše vremena provode gledajući crtane filmove, koristeći tablet i mobilne telefone, kompjutere, igrajući igrice. Neki roditelji navode da imaju malo vremena da predlažu igre svojoj deci, pa njihova deca pretežno biraju tehnologiju za zabavu u kući. Kod te grupe roditelja i dece, dominiraju igre u zatvorenom prostoru, pridaje se manja važnost igri na otvorenom. Roditelji navode da se deca igraju najčešće samostalno u konstruktivnim igrama (gradnja, crtanje), motoričkim aktivnostima (voze trotinete, bicikle, guralice, na motoričkom poligonu), a najmanje u igrama pretvaranja i igrama za razvoj imaginacije (lutkama, različitim materijalima kojima se menja namena, koriste se kao simboli). Za 
ovu grupu dece može se zaključiti da su najviše prisutne motoričke i konstruktivne igre u odnosu na podelu igara prema E.Kamenov, a u odnosu na interakciju prema M.Duran igra se odvija bez interakcije sa odraslima.

Postoji jedan broj roditelja koji organizuje deci igru u dvorištu, napolju. Igra se najčešće odvija u pratnji roditelja, sa manjim brojem vršnjaka. Roditelji navode da „, deca retko igraju igre koje smo mi ranije igrali“, u igri učestvuje dva ili manji broj igrača, nema velikog broja dece prisutnog u igri. Druga grupa roditelja daje važnost igri dece na otvorenom, manje učestvuje u igri dece, a najviše brine o bezbednosti dece. I u drugoj grupi dece najviše su prisutne motoričke igre, gde je prisutna interakcija sa drugom decom uglavnom na otvorenom prostoru.

Treća grupa roditelja podržava igru dece sa pravilima (igra „na slovo na slovo“, „ne ljuti se čoveče“, žmurke, jurke, igre skrivanja predmeta, igre loptom) i imitativne igre i igre uloga (u restoranu, kostimiranje, u prodavnici, majstorske radionice). Ova grupa roditelja je u interkaciji sa decom u igrama sa pravilima i imitativnim i igrama uloga.

\section{Materijali i sredstva za igru}

Po rečima roditelja, deca se najviše igraju gotovim igračkama za „simboličko izražavanje“ (Pravilnik o osnovama programa predškolskog vaspitanja i obrazovanja, „Godine uzleta“, 2018: 24) u imitativnim igrama (lutkama, figuricama super junaka, modelima životinja), „za istraživanje i konstruisanje“ (Pravilnik o osnovama programa predškolskog vaspitanja i obrazovanja, „Godine uzleta“, 2018: 24) u igrama građenja (puzlama, kockama), podsticanje motorike (bicikl, guralice, trotineti).

Koriste i prirodne materijale (zemlju, pesak, kamenje, pokošenu travu, grančice, lišće) koriste uglavnom u igrama na otvorenom za ,istraživanje i konstruisanje znanja“ (Pravilnik o osnovama programa predškolskog vaspitanja i obrazovanja, „Godine uzleta“", 2018:24). Današnja deca imaju dosta kamiona, traktora, prikolica koju mogu da iskoriste za igru sa prirodnim materijalima (da prenose, prevoze), ali ih koriste isključivo u kućnim uslovima, pa je igra manje kreativna. Igre na otvorenom se odvijaju na uređenim igralištima, gde ima sprava, a manje se koriste prirodni materijali u igri.

\section{Podrška i uloga roditelja u igri dece}

Analizirajući izveštaje o igri i aktivnostima dece i roditelja u kućnim uslovima tokom pandemije, uočeno je da se roditelji uključuju u igru dece po pozivu deteta, ali da ne obogaćuju igru novim materijalima i ne proširuju je. Više kupuju gotove igračke deci, a manje u igri koriste polustruktuirani, ambalažni i prirodni materijal, koji je izazovniji za decu. Upotrebom gotovih sredstava ne stimulišu se deca dovoljno da na maštovit način koriste sredstva, pa je igra jednolična i manje kreativna.

Na osnovu ispitivanja učešća roditelja u igri, roditelji najviše obezbeđuju prostor i igrovne materijale i na taj način „omogućavaju deci različite izbore kroz različita 
sredstva i materijale i načine izražavanja“ (Pravilnik o osnovama programa predškolskog vaspitanja i obrazovanja, „Godine uzleta“, 2018: 26). Manje vremena provodi u interakciji, kao aktivni posmatrač koji sluša i uključuje se u dijalog i kao partner u neposrednoj igri sa decom.

Rezultati su nam pokazali da ima jedan broj roditelja koji idealizuju dečju igru, ne uključuju se i ne ulaze u dečji igrovni prostor. Kažu ,,nekada nemam dovoljno vremena da joj se posvetim u njenim igranjima" $\mathrm{i}$, lepo se igra sam, nema potrebe da se uključujem".

Druga grupa roditelja iz uloge tutora u igri podučava i govori „pokušavam da ga navedem da nacrta pravilno ili da izgovori pravilno“, „pričam im šta da rade i kako da se igraju“.

Treća grupa roditelja učestvuje sa decom u igri, kao partneri, „podržava decu da zajednički predviđaju, zamišljaju, postavljaju pitanja jedni drugima i traže različite načine rešavanja problema" (Pravilnik o osnovama programa predškolskog vaspitanja i obrazovanja, „Godine uzleta“, 2018: 26), uzdržava se od vođenja igre, to prepušta detetu, a on sluša, prati dete i odgovara na dečje predloge, ravnopravno se uključuje u igru sa njim. Roditelj nije iznad deteta, ne vidi se ta asimetrična komunikacija između njih i roditelj ne pokazuje svoje iskustvo, već prihvata, podržava i obogaćuje iskustvo deteta. U primeru zamišljene igre zmaja i viteza roditelj navodi „, rekao mi je da želi da uhvati zmaja, a ja sam mu pomogla da se obuče u viteza i nastavili smo zajedno da ga lovimo na razne načine".

Ulogu partnera ili učesnika u igri roditelj ima u igri sa pravilima (igri žmurke, jurke, igre loptom, društvenim), igrama uloga (kuvar, prodavca, mama i dete, doktor, policajac) u kojima se „razvija zajedništvo kroz podsticanje uzajamne podrške, prihvatanja, uvažavanja, isticanje vrednosti zajedničkog doprinosa“ (Pravilnik o osnovama programa predškolskog vaspitanja i obrazovanja, „Godine uzleta“, 2018: 26). Igre u kojima se uključuju kao partneri, su mahom igre sa pravilima koje su im već poznate po iskustvu stečenom u detinjstvu.

Najčešće u takvim igrama deca su pobednici i inicijatori igre, pozivaju roditelje u igru, daju predloge. Roditelj je uzor, pokazuje kako se može odvijati igra. Tako kada deci nedostaju ideje u igri građenja roditelji pokazuju kako se može graditi, kako se može nešto nacrtati. Roditelji su i ravnopravni igrači brane na golu, skrivaju se u igrama žmurke, spremaju ručak u izmišljenom restoranu, bacaju kamenčiće i igraju školice. Roditelji navode da tokom igre i oni nauče nešto novo i da uživaju u igri sa svojom decom. Manji broj roditelja sa decom igra igrice na kompjuteru.

Veći broj roditelja smatra da deci „kvari“ igru, prekidajući ih da ručaju, da se spremaju za spavanje ili skupljaju igračke zbog nereda u kući. Navode i da svojim pitanjima, koja nisu adekvatna u tom trenutku ,kvarimo igru, želeći da pokažemo kako se igra može odvijati, a dete to ne želi u tom trenutku "; zabranama da nešto isprobaju novo; upućenim rečima „,ne prljaj“, , ,uspori“", iz straha da se ne povrede, „pričajući im kako da se igraju a oni žele po njihovim pravilima". Često ograničavaju i vreme i 
kretanje (da ne skače, da ne trči, da se ne penju) ili „,prekinemo dete dok mašta“. Deca burno reaguju na „kvarenje“ igre, ljute se, plaču, odustaju. Mali broj roditelja smatra da ne ometa dečju igru i da svaki put kada se roditelj umeša u igru dece, deci prija.

Najveći broj roditelja učestvuje u igrama sa pravilima, jer se najlakše odigravaju. Dozvoljavaju deci da budu pobednici u igrama kako ih ne bi frustrirali. Iako roditelji kažu da se često uključuju u dečju igru, to njihovo uključivanje često remeti tok dečje igre i neki put je naruši, jer roditelji daju predlog za igru na osnovu svog iskustva koje imaju. Daju drugačiji smer, što često naruši igru jer dečji plan je drugačiji.

Često provode vreme vozeći decu na biciklu ili guralici (decu mlađeg uzrasta), čime ne podstiču dečji razvoj. Mnogo vremena provede u parkovima gde je uvek prisutan roditelj u ulozi posmatrača i čuvara. Mali broj roditelja je učesnik u igri koji preuzima aktivnu ulogu i ulogu partnera. Tokom igre u parku, roditelji manje sagledavaju potrebu deteta da učestvuje u aktivnostima koje donose rizik, koje su deci interesantne i izazovne da ih savladaju, zbog velike zabrinutosti da se ne povrede i ugroze svoju bezbednost.

Roditelji se uključuju najčešće u igru sa pravilima, a mali broj roditelja učestvuje i igra se „rame u rame“ sa detetom gradeći igru. Dete trebe da se shvata kao kompetentno, da ono ima potencijale i da treba da nađe svoj način i put da ih razvije. Igre koje su roditelji najviše igrali u svom detinjstvu, učili su i svoju decu da ih igraju. Jedan broj roditelja navodi da se sada deca drugačije igraju i da nema igara koje su oni igrali. Navode da treba da veći broj dece učestvuje u igrama i da se one odvijaju napolju.

\section{Podržavanje roditelja u bogaćenju dečje igre}

Prateći interesovanja dece, ponudili smo roditeljima putem Viber grupa, različite načine podrške dečjoj igri i različite materijale i vrste igara prateći interesovanja dece. Želeli smo da oplemenimo igru dece i unapredimo interakciju dece i roditelja. Predložene su igre za koji je potrebno više koristiti predmete iz svakodnevne upotrebe, ambalažne i nestruktuirane materijale, tokom kojih se uključuju odrasli u igri.

Analizirajući igre koje su na početku pandemije roditelji organizovali sa decom u kućnim uslovima i njihovu ulogu u tim igrama i igre nastale predlogom vaspitača, stručnih saradnika, zaključeno je da je uloga roditelja pomerena od pasivnog posmatrača, kontrolora, na ulogu aktivnog posmatrača i partnera. Uloga roditelja je bila podržavajuća sa posebnim akcentom na pripremi sredine za istraživanje i učenje. Roditelji i deca su sami počeli da smišljaju njihove nove igre i predstavljaju ostaloj deci i roditeljima

Praćenjem dečje igre nakon predloga od strane praktičara, uočeno je da su deca više koristila nestruktuirani (testo, voda) i ambalažni materijal (kartonske kutije, rolne ubrusa, kanap, oklagije, papir) i prirodni materijal (drvo, kamen). U takvim igrama uloga odraslog je podrazumevala:

- prikupljanje materijala što omogućava ,različite izbore kroz različita sredstva i materijale" (Pravilnik o osnovama programa predškolskog vaspitanja i obrazovanja, „Godine uzleta“, 2018: 26) 
- uvažavanje ideja dece što „podstiče decu da koriste govor u tumačenju svojih misli, doživljaja i da proširuju svoje razumevanje smisla sveta kroz govorno izražavanje... podstiče razvijanje različitih vrsta rane pismenosti““ (Pravilnik o osnovama programa predškolskog vaspitanja i obrazovanja, „Godine uzleta“, 2018: 26)

- izradu sredstva za igru zajedno sa detetom, što za razultat ima partnerstvo sa detetom u neposrednoj igri i „kreativne načine izražavanja“ (Pravilnik o osnovama programa predškolskog vaspitanja i obrazovanja, „Godine uzleta“, 2018: 26)

- istraživanje, koje omogućava da se deca „bave onim što za njih ima smisla, što ih čudi i zanima...fokusira se na proces učenja ne produkt...zajednički predviđaju, zamišljaju, postavljaju pitanja jedni drugima i traže različite načine rešavanja problema“" (Pravilnik o osnovama programa predškolskog vaspitanja i obrazovanja, „Godine uzleta“, 2018: 26)

- davanje predloga novog načina igranja, što podstiče decu „da povezuju sa prethodnim iskustvom i znanjem...razvijaju proaktivni odnos prema svetu kroz uvažavanje inicijative, prava na izbor, pokretanje zajedničkih akcija“" (Pravilnik o osnovama programa predškolskog vaspitanja i obrazovanja, „,Godine uzleta“, 2018: 26)

Roditelji su istakli da su deci bile nainteresantnije igre sa pravilima: „kula od knjiga“, „pogodi metu“ (gađanje avionima od papira i lopticama), ,pojedi špagete“ (namotavanje klupka), igre memorija, poligone sa preprekama, igre skrivanja predmeta, kao i simboličke i igre uloga: piknik, kostimiranje u odrasle i mnoge druge (Gardašević A., 2020)

Po rečima roditelja deci su bili izazovni materijali koji nisu gotova igrovna sredstva. Deca su istraživala njihovu upotrebu, koristila ih na različite načine, nalazila im različite namene ,, dezodorans kao mikrofon “, ,,drvca od sladoleda služe nam za pregled kod lekara “, „koriste različitu odeću za maskiranje u superheroje, policajce“, „,kanap i grane za pecanje“. Korišćeni su predmeti iz realnog života, kojima je preoblikovana namena , stetoskop u igri lekara“, ,štipaljke kao ogradicu ili za pravljenje robota “.

Nastale igre u saradnji sa roditeljima, decom, vaspitačima i saradnicima su obezbedile bolji položaj deteta u porodici, bolje razumevanje načina učenja deteta, sagledavanje njegovih trenutnih potreba za saznajem i istraživanjem. Produbljivanje i bogaćenje dečje igre je stvaralo kvalitetnije interakcije između roditelja i deteta.

\section{Zaključak i pedagoške implikacije}

Sagledavši igru roditelja u detinjstvu uočeno je da dominiraju motoričke igre uz učešće druge dece bez nadzora odraslih. Igra je bila zabavnija jer je nosila veći rizik. $\mathrm{U}$ igri su bila prisutna deca različitog uzrasta i starija deca su brinula o mlađima. Igre 
su se odvijale na otvorenom, svakodnevno u prirodi bez obzira na vremenske uslove uz upotrebu prirodnog materijala u igri.

Igra današnje dece je usamljenička, jer je prisutan mali broj vršnjaka, igra se odvija najviše gotovim igračkama, pretežno u zatvorenom prostoru. Odrasli su najviše u ulozi pasivnih i aktivnih posmatrača u igri. Podrška roditelja u igri kreće od idealizacije, neuključivanja u igru, do intervencije u kojima roditelj preuzima vodeću ulogu u igri. U kućnim uslovima deca imaju malo prilika da se igraju sa drugom decom, pa je zato uloga roditelja kao saigrača i partnera više potrebna deci.

Kod roditelja treba razviti svest o njihovom učešću i njihovom doprinosu igri kako bi ta igra dobila na kvalitetu, a dete emotivnu potporu i jaču vezu između njega i roditelja. Uloga odraslih treba da bude podržavajuća, jer zajedničko igranje dece i roditelja je više inspirativno za dete. Roditelj treba da bude osetljiv, da prepozna u kom trenutku treba da se uključi, a da ne naruši dečji iluzorni plan igre, već da podrži razvoj stvaralačkih sposobnosti i razvojnih kompetencija deteta. Pažljivo slušanje deteta ohrabruje dete u igri, podupire dečje aktivnosti, razija dečje kapacitete prateći tok igre. Odrasli treba da umeju nenametljivo da podrže nove ideje i obezbede sredstva i materijale kako bi proširili igru. Neizvesnost o toku igre kada roditelj učestvuje „rame uz rame" sa detetom doprinosi razvijanju kompetencija kod deteta za kreiranje različitih igara, što doprinosi razvoju stvaralaštva i razvoju samopouzdanja. U tokvoj ulozi ne vidi se asimetrični položaj roditelja u odnosu na dete, već ravnopravan koji donosi osećaj ushićenja, zadovoljstva i poverenja u sopstvene snage i moći.

Zbog nemogućnosti igranja sa vršnjacima, posebno u vreme pandemije, važan je način na koji se roditelj uključuje u igru sa decom, pa je potrebna podrška roditeljima o sagledavanju svoje uloge u igri sa decom i načinima na koje oni mogu tu igru da unaprede. Za one koji se profesionalno bave decom, veliki izazov je da se aktivnije uključe u razvijanju roditeljskih kompetencija u podržavanju deteta i dečje igre.

\section{HOW SUPPORTED IS A CHILD IN PLAYING AT HOME}

\section{Abstract}

The paper presents and analyses the results obtained by researching children's play and parental support for children at home during the Covid-19 pandemic. Play is a natural way of learning in a child's life, but parents often use it to solve educational tasks and turn play into teaching. The starting point of the research is the need for analyzing parents' role in relation to the theoretical analysis of the desirable roles of adults in children's play. For parents the intention of the research is to evaluate, from their own perspective, their play when they were children and their children's play and to see their own role, which they take on during the game. The results indicated that 
parents' play when they were children was of better quality than their children's play today and that their children's play is more solitary. Parents take on an indirect role in supporting children's play, they are less directly involved in children's play. They are more in the role of observers, and the least as helpers and partners in the game. The results obtained in this way were the starting point for taking steps that would contribute to better support and establishment of partnerships in the game of children and adults. The next step was to present the possible children's play at home, where the role of parents was moved from the role of observers to the role of team mates and partners.

Keywords: game, context, participation, game stimulation strategy

\section{Literatura}

Badurina, P. (2015). Uloga odgojitelja u simboličkoj igri djece rane dobi, Napredakčasopis za pedagogijsku teoriju i praksu, 156 (1-2), 47-75.

Colić, V. i Milošević, G. (2019): Učešće roditelja i vaspitača u igri dece, U: D. Pavlović Breneselović, G. Stepić i I. Prlić (ur.), Zbornik radova "Inicijalno obrazovanje i stručno usavršavanje vaspitača - partnerstvo u građenju kvaliteta (str. 160-175), Sremska Mitrovica, Visoka škola strukovnih studija za vaspitače i poslovne informatičare u Sremskoj Mitrovici.

Duran, M. (2001): Dijete i igra, Retrived Januar 2021 https://kupdf.net/download/duran-dijete-i-igra 58c715e8dc0d60124233902e pdf

Gardašević M.A. (2020): Igre iz perspective deteta. Retrieved Februar 2021 https:// padlet.com/anagardasevic/9hhk03fc90uqv1kh

Leong D., Bodrova E. (2005). The Importance of Play: Why Children Need to Play, file:///C:/Users/ana.gardasevic/Downloads/WhyChildrenNeedPlayScholastic2005.pdf

Kamenov E. (2006). Dečja igra, vaspitanje i obrazovanje kroz igru. Beograd: Zavod za udžbenike.

Krnjaja, Ž. (2012). Igra na ranim uzrastima, U: Standardi za razvoj i učenje dece ranih uzrasta u Srbiji (113-132). A. Baucal (ur.). Beograd, Filozofski fakultet, UNICEF.

Matejić Đuričić Z. (2012): Nove konceptualizacije razvoja i vaspitanja. Specijalna edukacija i rehabilitacija 11 (2). 267-284

Marjanović A. (1987). Dečji vrtić kao otvoren sistem. Predškolsko dete (1-4) . Savez pedagoških društava Jugoslavije. Beograd.

Meakin, Timothy P. (2005). Sociodramatic Play and Child Development. Retrieved Februar 2021 https://oro.open.ac.uk/47023/1/Thesis-D_pm1.pdf

Nives M. (2015). Igra djece predškolske dobi, (završni rad). Pula: Sveučilište Jurja Dobrile Odjel za odgojne i obrazovne znanosti. 
Osnove programa predškolskog vaspitanja i obrazovanja (2018). Pravilnik o osnovama programa predškolskog vaspitanja i obrazovanja „Godine uzleta“. Službeni glasnik RS, br. 27, 2018.

Peter Smith K., Pellegrini A. (2013). Play. Retrived januar 2021 http://www.child-encyclopedia.com/sites/default/files/dossiers-complets/en/play.pdf

Pavlović Breneselović (2012). Odnosi na radnim uzrastima. U: Standardi za razvoj $i$ učenje dece ranih uzrasta u Srbiji. (133-146). A. Baucel (ur). Beograd, Filozofski fakultet, UNICEF.

Rinald C.(2001). The pedagogy of listening, Retrieved Februar 2021 https://static1.squarespace.com/static/526fe9aee $4 b 0 \mathrm{c} 53 \mathrm{fa} 3 \mathrm{c} 845 \mathrm{e} 0 / \mathrm{t} / 540 \mathrm{fce} 31 \mathrm{e} 4 \mathrm{~b}-$ 00c94d884e002/1410321969279/Pedagody+of+Listening+-+Rinaldi+-+Fall+2001.pdf 